\title{
INFLUENCE OF ARTIFICIAL AGING ON THE ELECTROCHEMICAL PROPERTIES OF THE ALUMINIUM AA 6063 ALLOY
}

\author{
VPLIV UMETNEGA STARANJA NA ELEKTROKEMIJSKE \\ LASTNOSTI ALUMINIJEVE ZLITINE AA 6063
}

\author{
Črtomir Donik \\ Institute of Metals and Technology, Lepi pot 11, 1000 Ljubljana, Slovenia \\ crtomir.donik@imt.si \\ Prejem rokopisa - received: 2017-10-05; sprejem za objavo - accepted for publication: 2017-11-14
}

doi:10.17222/mit.2017.168

\begin{abstract}
The influence of artificial ageing on the corrosion behaviour of the aluminium alloy AA 6063 in chloride-containing solutions was studied to determine the correlation between aging parameters and corrosion through the electrochemical parameters. The present study showed that LM and standard SEM imaging with EDS observation does not expose significant differences for the artificially aged aluminium. Nevertheless, a special statistical technique with observation of the larger area showed a significant increase of the smallest precipitates which are the initial sites for the corrosion. With electrochemical measurements, we corroborated that increase of corrosion rate is directly connected to the number of precipitates and not with the total area of exposed precipitates. Scanning electron microscopy observations combined with EDS measurements were used also to establish the type of precipitates in the studied alloy.

Keywords: aluminium, artificial aging, SEM, electrochemical measurements
\end{abstract}

Raziskovali smo vpliv umetnega staranja na korozijske lastnosti aluminijeve zlitine AA 6063 z namenom ugotoviti soodvisnost med staranjem in elektrokemijskimi parametri. V raziskavi smo dokazali, da zgolj standardni pregled s svetlobnim in vrstičnim elektronskim mikroskopom v kombinaciji z EDS-analizo na prvi pogled ne pokaže bistvenih razlik med različno toplotno obdelanimi vzorci. Ugotovili smo, da s pomočjo preiskave na večjem področju in s statistično obdelavo lahko odkrijemo povezave predvsem med manjšimi izločki in elektrokemijskimi parametri. S korozijskimi meritvami smo tudi potrdili, da je povečanje korozijske hitrosti direktno povezano s številom majhnih izločkov in ne s seštevkom površine vseh izločkov. S SEM-analizo y kombinaciji z EDS-analizo smo uporabili za določitev vrst vključkov v preiskovani zlitini.

Ključne besede: aluminij, umetno staranje, SEM, elektrokemijske meritve

\section{INTRODUCTION}

AA 6063 is an aluminium alloy, with magnesium and silicon as the main alloying elements and iron as impurity. It has generally good mechanical properties, is heat treatable and weldable. AA 6063 is the most common aluminium alloy used for extrusion. It allows complex shapes to be formed with very smooth surfaces fit for further anodizing and so is popular for visible architectural applications such as window frames, door frames, roofs, and sign frames. These alloys find application in the artificial aging condition, which makes it possible to obtain excellent mechanical properties. ${ }^{1-12}$ The physical properties exhibited by aluminium alloys are significantly influenced by the treatment of the sample. In all the above-mentioned applications, alloys are prone to corrode, while also exposed to severe atmospheric environments. ${ }^{13-17}$

The physical properties of aluminium alloys are significantly influenced by the sample treatment. A standardized system has been developed to designate these treatments. T1 thermal treatment means aluminium alloy cooled from an elevated temperature shaping process and naturally aged to a substantially stable condi- tion. T1 tempered AA 6063 used in our study, has an ultimate tensile strength of at least $120 \mathrm{MPa}$. Applications requiring higher strength typically use other alloys, such as AA 6061 or AA 6082 instead. ${ }^{18,19}$ In our study, we aged the alloy even further to evaluate the electrochemical properties correlated to the aging processes. Corrosion of the aluminium alloys are directly linked to the numbers of the impurities, inclusions, precipitates areas of different electrochemical potential as bulk metal, while these spots are initial sites for pitting and local, general corrosion. Corrosion mode evolution with aging stage at aging temperature of $150{ }^{\circ} \mathrm{C}$ and $175{ }^{\circ} \mathrm{C}$ follows the following order: pitting and local IGC (early aging), general IGC (under-aged), local IGC with pitting (near peak-aged), and pitting (over-aged). At elevated aging temperature of $200{ }^{\circ} \mathrm{C}$, the corrosion mode evolves much faster. ${ }^{1,20-23}$ Therefore, we used little over $200{ }^{\circ} \mathrm{C}$ in our study to intensify and accelerate the precipitation in the AA6063 alloy. Aging of studied AA6063 alloy exhibited characteristic precipitation hardening phenomena. The precipitation hardening process requires that the second component in the aluminium alloy, is sufficiently soluble to allow extensive dissolution at an 
elevated temperature (solubilisation treatment temperature) and that the solubility is reduced at lower temperatures like $\mathrm{Si}$ and $\mathrm{Fe}$ in our case. ${ }^{2,24,25}$

The aim of the presented study was to determine the aging effect on corrosion stability in differently artificially aged aluminium alloy AA6063.

\section{MATERIAL AND METHODS}

\subsection{Material}

The chemical compositions of the studied alloy was determined using X-ray fluorescence spectrometer XRF (Thermo Scientific Niton XL3t GOLDD+).

Table 1: Chemical composition in mass fractions, $(w / \%)$

\begin{tabular}{|c|c|c|c|c|}
\hline $\mathrm{Fe}$ & $\mathrm{Cr}$ & $\mathrm{Si}$ & $\mathrm{Mg}$ & $\mathrm{Al}$ \\
\hline 0.17 & 0.14 & 0.51 & 0.65 & balance \\
\hline
\end{tabular}

\subsection{Sample aging}

Samples for the study were treated with normal T1 treatment (sample T1) and afterwards artificially aged on $204{ }^{\circ} \mathrm{C}$ for $1 \mathrm{~h}$ (sample $\mathrm{T} 1+1 \mathrm{~h}$ ) and others were treated for additional $5 \mathrm{~h}$, together $6 \mathrm{~h}$ (sample $\mathrm{T} 1+6 \mathrm{~h}$ ).

\subsection{Light Microscopy (LM)}

Used Nikon Microphot FXA optical microscope with Olympus ${ }^{\circledR}$ DP73 3CCD video camera and StreamMotion ${ }^{\circledR}$ software for metallographic image analysis in dark-field mode. The samples for dark-field mode was prepared with modified Keller's etching solution for $10 \mathrm{~s}$.

\subsection{Scanning Electron Microscopy (SEM)}

Field Emission Scanning Electron Microscope JEOL $®$ JSM-6500F with attached Energy Dispersive X-ray spectroscopy EDS (INCA ENERGY® 400) Oxford, Wave Dispersive X-ray spectroscopy WDS (INCA WAVE® 700) Oxford and Electron Back Scattered Diffraction EBSD (HKL Channel5®) were employed to investigate the morphology of the different polished surfaces of AA6063 as well as the morphology and distribution of the precipitates evaluation and EDS measurements. The statistical lateral distribution of the precipitates was determined by INCA ENERGY add-in called Feature ${ }^{\circledR}$, which shows and calculate the number of precipitates etc., which were later statistically shown as histogram of the number of the particles in correlation with their size.

\subsection{Electrochemical measurements}

Electrochemical measurements were performed on prepared specimens, ground with $\mathrm{SiC}$ emery paper down to 4000 grit and polishing down to $1 \mu \mathrm{m}$ with a diamond suspension. The experiments were carried out at room temperature in a 3,5\% NaCl from Merck, Darmstadt, Germany, and stabilized at $\mathrm{pH}=7$. The measurements were performed using a three-electrode, flat BioLogic $\AA$ corrosion cell (volume $0.25 \mathrm{~L}$ ). The test specimen was employed as the working electrode (WE). The reference electrode (RE) was a saturated calomel electrode (SCE, $0.242 \mathrm{~V}$ vs. SHE) and the counter electrode (CE) was a platinum mesh. Electrochemical measurements were recorded using a BioLogic $®$ Modular Research Grade Potentiostat/Galvanostat/FRA Model SP-300 with an EC-Lab® software V11.10. The specimens were immersed in the solution $1 \mathrm{~h}$ prior to the measurement in order to stabilize the surface at the open-circuit potential (OCP). The cyclic voltametry measurements were recorded after $1 \mathrm{~h}$ sample stabilization at the open-circuit potential (OCP), starting the measurement at $250 \mathrm{mV}$ vs. SCE more negative than the OCP. The potential was then increased, using a scan rate of $1 \mathrm{mV} \mathrm{s}^{-1}$. All the measurements were made at room temperature and were repeated at least three times. The linear polarization measurements were performed at $\pm 25 \mathrm{mV}$ according to the OCP, using a scan rate of $0.01 \mathrm{mV} \mathrm{s}^{-1}$.

\section{RESULTS AND DISCUSSION}

\subsection{Light microscopy images}

Figure 1 shows the images with special mode in LM, called dark-field, which best shows the grain boundaries in aluminium alloys. Just from the observation of the LM (Figure 1) and SEM BE images (Figure 2) the number and distribution of the precipitates (in our case $\mathrm{Al}-\mathrm{Si}$-Fe-phases), we cannot determine that the number
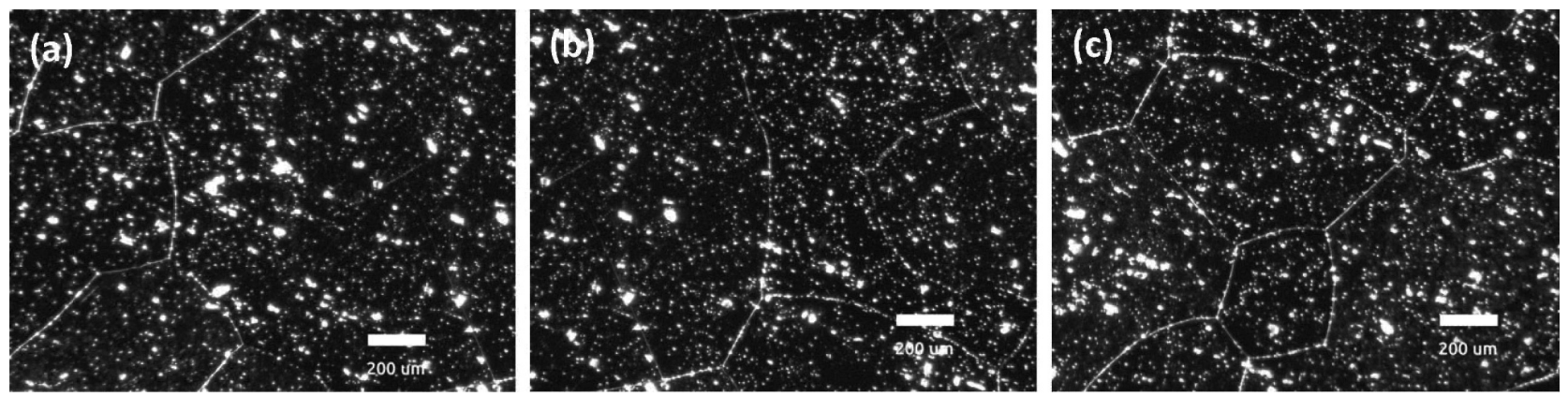

Figure 1: LM darkfield images with 100× magnification of: a) T1, b) $\mathrm{T} 1+1 \mathrm{~h}$ and c) $\mathrm{T} 1+6 \mathrm{~h}$ 

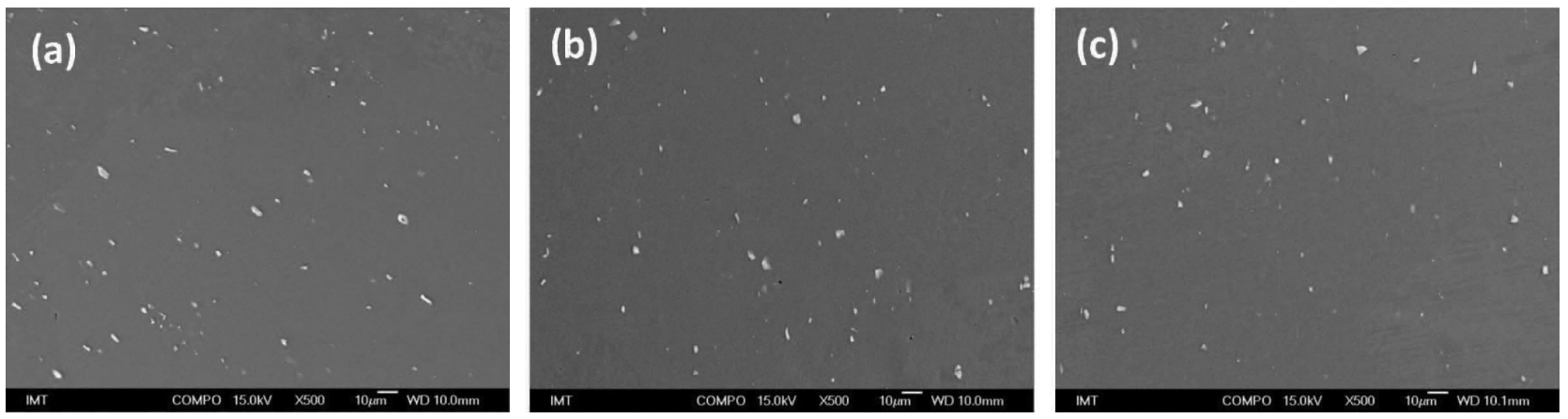

Figure 2: BE images with 500x magnification of samples: a) T1, b) T1+1 h and c) T1+6 h

is increasing with the thermal treatment - aging. With the exquisitely exposed grain boundaries in the Figure 1, also the grain size is neither increased or decreased with aging. As known from ${ }^{2,24}$, the last is known fact by the aging. It is accomplished by nucleation and growth process in the grains, while the size of the grains remains unchanged.

\subsection{SEM images}

Figure 2 shows SEM backscatter images of the polished aluminium alloy with lighter shade for heavier elements - in our case Fe phases. As known, typical Fe phases in aluminium alloys are in the $\mathrm{Al}-\mathrm{Fe}-\mathrm{Si}$ system, the ternary phases that can be in equilibrium with aluminium are the $\alpha-\mathrm{Al}_{8} \mathrm{Fe}_{2} \mathrm{Si}(31.6 \% \mathrm{Fe}, 7.8 \% \mathrm{Si})$ with a Chinese script morphology, $\beta-\mathrm{Al}_{5} \mathrm{FeSi}(25.6 \% \mathrm{Fe}$, $12.8 \% \mathrm{Si}), \delta-\mathrm{Al}_{4} \mathrm{FeSi}_{2}(25.4 \% \mathrm{Fe}, 25.5 \% \mathrm{Si})$ and $\gamma-\mathrm{Al}_{3} \mathrm{FeSi}(33.9 \% \mathrm{Fe}, 16.9 \% \mathrm{Si})$ phases. $^{26}$ Since EDS measurements of the precipitates (Figure 4 and Table 2), with morphology not similar to Chinese script, we could conclude that most likely $\alpha-\mathrm{Al}_{8} \mathrm{Fe}_{2} \mathrm{Si}$ phases are present in the precipitates. On the other hand, similarly as from LM images, with just observation, we cannot determine that the number of the inclusions increase with aging. This is the reason the special add-in called Feature ${ }^{\circledR}$ in INCA ${ }^{\circledR}$ Oxford package was used for larger area observation. In our study $1 \mathrm{~mm}^{2}$ with $1500 \times$ magnification, to

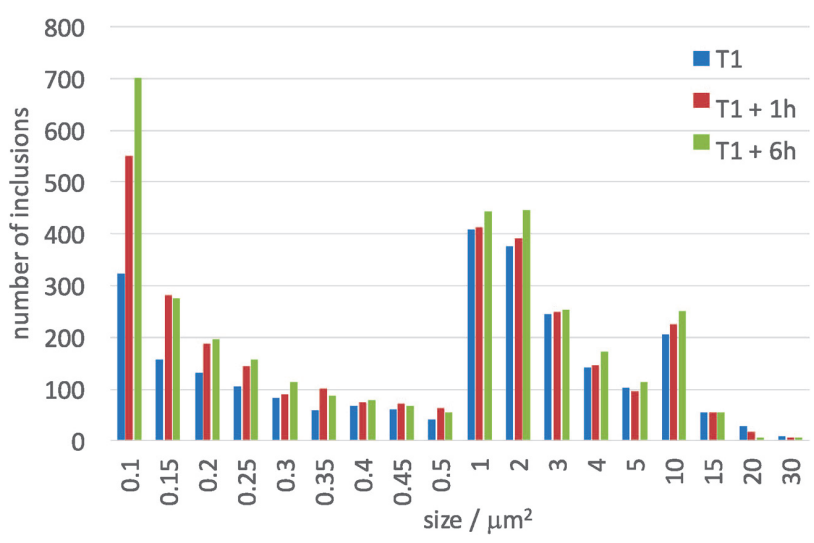

Figure 3: Histogram of precipitate distribution of variously aged samples determine also the particles smaller than $0.1 \mu \mathrm{m}^{2}$ was used. Figure 3 shows the histogram for all the analysed samples. The particles are counted just on the bases of the different shade of grey and not the EDS analysed chemistry. The sum of all the particle analysed drastically differ from each other: T1 2592 precipitates, $\mathrm{T} 1+1$ h 3154 precipitates and $\mathrm{T} 1+6$ h 3472 precipitates. The increase of the number of inclusions is more than $33 \%$ between samples $\mathrm{T} 1$ and $\mathrm{T} 1+6 \mathrm{~h}$. On the other hand, if you additionally weight this numbers with the size and calculate the sum area of the inclusions, the increase is merely $7 \%$ for $\mathrm{T} 1+6 \mathrm{~h}$ as anticipated. T1 treatment expose almost all the inclusions and with aging bigger phases dissolve to smaller and the number increases. For the corrosion rate, the number of the precipitates and not the area of the impurities on the surface, play the crucial role.

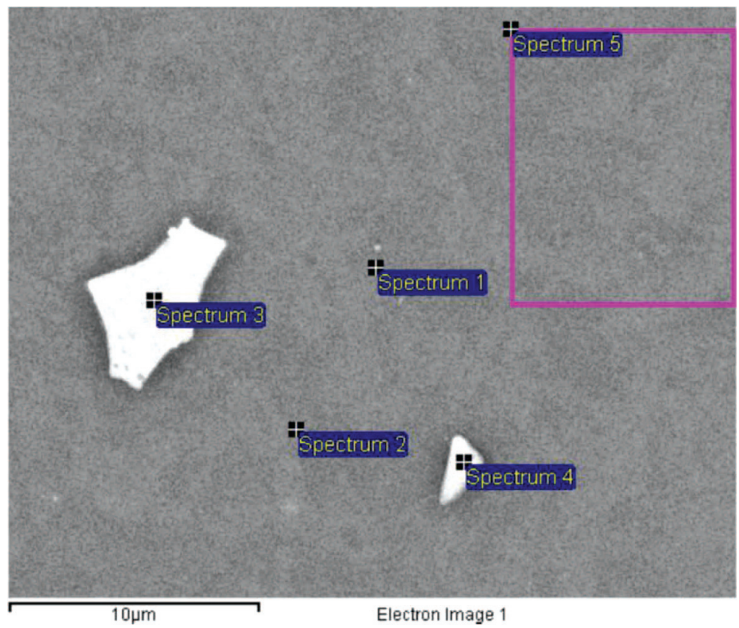

Figure 4: BE image with spots and areas of EDS analyses on polished sample T1

Table 2: EDS analyses for spots and areas from Figure 4 in mass fractions, $(w / \%)$

\begin{tabular}{|c|c|c|c|c|}
\hline & $\mathrm{Mg}$ & $\mathrm{Al}$ & $\mathrm{Si}$ & $\mathrm{Fe}$ \\
\hline Spectrum 1 & 0.6 & 94.4 & 1.7 & 3.3 \\
\hline Spectrum 2 & 0.5 & 91.5 & 2.0 & 6.0 \\
\hline Spectrum 3 & 0.3 & 69.3 & 6.4 & 24.0 \\
\hline Spectrum 4 & 0.4 & 84.0 & 3.4 & 12.2 \\
\hline Spectrum 5 & 0.5 & 99.2 & 0.3 & 0.0 \\
\hline
\end{tabular}




\subsection{EDS measurements}

Figure 4 shows the analysed area and spots of the polished sample T1. EDS measurements were performed only on T1, while all the samples have the same chemistry and also the precipitates have the same composition. Spectrum 1 and 2 (Table 1) shows the composition of the smallest inclusion - these are $0.1 \mu \mathrm{m}^{2}$ or less. The EDS technique also measures a lot of the surrounding area/analysing volume, so we can just speculate that the chemical composition of small precipitates is probably similar as in the biggest precipitates. The bigger precipitates are measured in Spectrum 3 and 4, and are as we described above most probably, $\alpha-\mathrm{Al}_{8} \mathrm{Fe}_{2} \mathrm{Si}$. Spectrum 5 analysed the area of the base material, aluminium alloy AA 6063 with just $0.3 \%$ of mass fractions of $\mathrm{Si}$ and $0.5 \%$ of mass fractions of $\mathrm{Mg}$, similar as shown in the chemical composition of the material.

\subsection{Electrochemical measurements}

Figure 5 shows cyclic voltamogramm of all three samples. The curves of the voltamogramm shows that the thermal treatment increase the corrosion current and also the shape of the loop of the voltamogramme, which is directly connected to the oxidation of the metal which means increased general corrosion of the studied alloy.

Figure 6 shows linear polarization curves for the AA6063 samples in 3,5\% NaCl solution at $\mathrm{pH}=7$. The calculations from linear polarization measurements were executed by using the Equation (1):

$$
R_{\mathrm{p}}=\beta_{\mathrm{a}} \beta_{\mathrm{c}} /\left(2.3 I_{\text {corr }}\left(\beta_{\mathrm{a}}+\beta_{\mathrm{c}}\right)\right)
$$

The polarization resistance, $R_{\mathrm{p}}$, is evaluated from the linear polarization curves by applying a linear leastsquares fit of the data around OCP, $\pm 10 \mathrm{mV}$. The corrosion current, $I_{\text {corr }}$, is calculated from $R_{\mathrm{p}}$, the least-squares slope, and the Tafel constants, $\beta_{\mathrm{a}}$ and $\beta_{\mathrm{c}}$, of $120 \mathrm{mV}$ decade $^{-1}$. The value of $E_{(I=0)}$ is calculated from the least-squares intercept. The corrosion rates were calculated by using the following conversion formula in Equation (2):

$$
v_{\text {corr }}=C(E W / d)\left(I_{\text {corr }} / A\right)
$$

where $E W$ is the equivalent weight of the sample in $\mathrm{g}, A$ is the sample area in $\mathrm{cm}^{2}, d$ is its density in $\mathrm{g} / \mathrm{cm}^{3}$, and

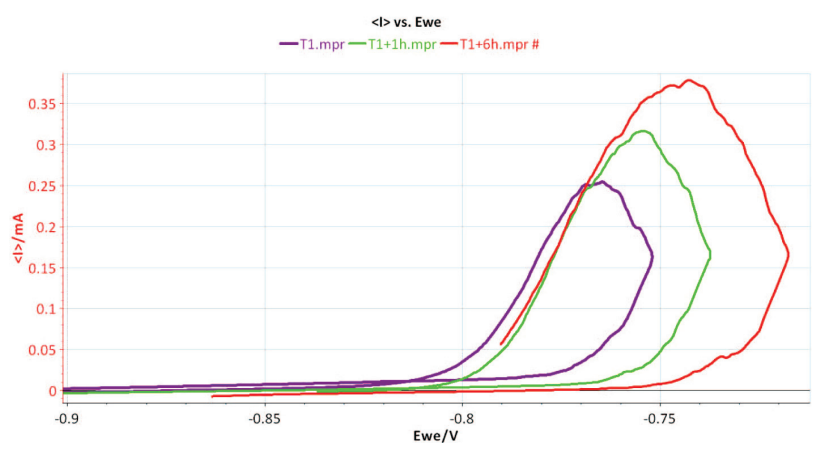

Figure 5: Cyclic voltamogramm of the samples in $\mathrm{NaCl}$

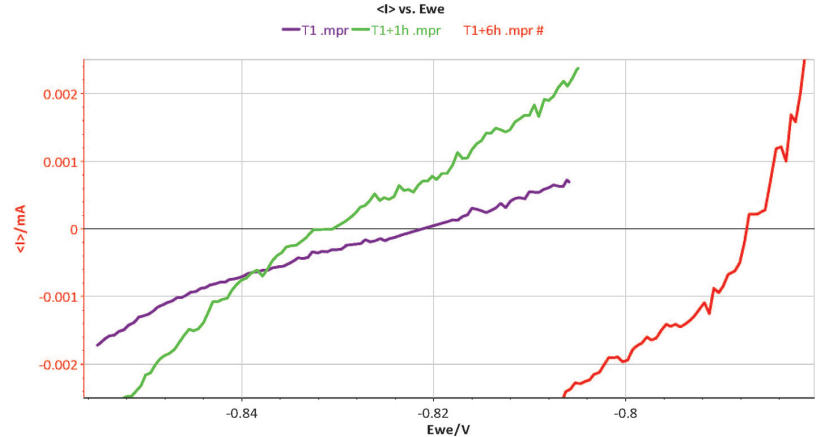

Figure 6: Linear polarization curves of the samples $\mathrm{T} 1, \mathrm{~T} 1+1 \mathrm{~h}$ and $\mathrm{T} 1+6 \mathrm{~h}$

$C$ is a conversion constant that is dependent upon the required units.

The steeper linear polarization curves means lower polarisation resistance $\left(R_{\mathrm{p}}\right)$ which is directly linked to higher corrosion currents $\left(I_{\text {corr }}\right)$. The corrosion parameters calculated from the linear polarization with potentiodynamic measurement data in a $3.5 \% \mathrm{NaCl}$ solution indicated that the corrosion stability is highest for the T1 sample followed by the sample treated by $\mathrm{T} 1+1 \mathrm{~h}$ and the lowest corrosion resistance belongs to $\mathrm{T} 1+6 \mathrm{~h}$ sample. Higher corrosion rate corroborates with the previously described fact that more inclusions means more corrosion initial points. This was proven with the higher corrosion currents $\left(I_{\text {corr }}\right)$, higher corrosion rates $\left(v_{\text {corr }}\right)$ and lower polarization resistances $\left(R_{\mathrm{p}}\right)$ (Table 3 ).

Table 3: Corrosion characteristics of studied materials calculated from linear polarisation curves

\begin{tabular}{|c|c|c|c|c|}
\hline & $\begin{array}{c}I_{\text {corr }} \\
/ \mu \mathrm{A}\end{array}$ & $\begin{array}{c}E_{\text {corr }} \\
/ \mathrm{mV}\end{array}$ & $\begin{array}{c}v_{\text {corr }} \\
/ \mu \mathrm{m} \text { year }^{-1}\end{array}$ & $\begin{array}{c}R_{\mathrm{p}} \\
/ \mathrm{k} \Omega\end{array}$ \\
\hline $\mathrm{T} 1$ & 0.281 & -820 & 2.35 & 24.9 \\
\hline $\mathrm{T} 1+1 \mathrm{~h}$ & 0.617 & -830 & 5.29 & 11.8 \\
\hline $\mathrm{T} 1+6 \mathrm{~h}$ & 0.906 & -785 & 7.65 & 3.02 \\
\hline
\end{tabular}

\section{CONCLUSIONS}

The AA6063 alloy was used with different thermal treatment times to determine the correlation between the number and size of precipitates and corrosion characteristics through electrochemical parameters in chloridecontaining solutions. Light-microscopy observations and standard SEM imaging with EDS do not show the big differences they should due to the big difference in the corrosion rates. INCA Feature ${ }^{\circledR}$ uses the observation of the larger area and helped us to explain the direct correlation between the smallest precipitates, which are initial sites for the pitting and general corrosion, and the corrosion rate. With scanning electron microscopy observations combined with EDS measurements we also determined the type of precipitates in the studied alloy. 


\section{Acknowledgement}

The authors acknowledge the financial support from the Slovenian Research Agency (research core funding No. P2-0132).

\section{REFERENCES}

${ }^{1}$ H. Maeng, Y. Choi, S.-J. Lee, Aging parameter for evaluating age hardening in Al alloys, Mater. Res. Express. 4 (2017), 76509, http://stacks.iop.org/2053-1591/4/i=7/a=076509

${ }^{2}$ R. R. R. Ambriz, D. Jaramillo, Mechanical Behavior of Precipitation Hardened Aluminum Alloys Welds, W.A. Monteiro (Ed.), Light Met. Alloy. Appl., InTech, Rijeka, 2014, doi:10.5772/58418

${ }^{3}$ Z. Xu, H. J. Roven, Z. Jia, Effects of cryogenic temperature and prestretching on mechanical properties and deformation characteristics of a peak-aged AA6082 extrusion, Mater. Sci. Eng. A. 679 (2017), 379-390, doi:10.1016/j.msea.2016.10.049

${ }^{4}$ B. Podgornik, I. Paulin, B. Zajec, S. Jacobson, V. Leskovsek, Peep cryogenic treatment of tool steels, J. Mater. Process. Technol., 229 (2016), 398-406, doi:10.1016/j.jmatprotec.2015.09.045

${ }^{5}$ D. Mandrino, I. Paulin, S. D. Skapin, Scanning electron microscopy, X-ray diffraction and thermal analysis study of the TiH2 foaming agent, Mater. Charact., 72 (2012), 87-93, doi:10.1016/j.matchar. 2012.07.005

${ }^{6}$ I. Paulin, Synthesis And Characterization of Al Foams Produced by Powder Metallurgy Route Using Dolomite and Titanium Hydride as a Foaming Agents, Mater. Tehnol., 48 (2014), 943-947

${ }^{7}$ X. Fan, L. Chen, G. Chen, G. Zhao, C. Zhang, Joining of 1060/6063 aluminum alloys based on porthole die extrusion process, J. Mater Process. Technol., 250 (2017), 65-72, doi:10.1016/J.JMATPROTEC 2017.07.009

${ }^{8}$ I. Paulin, Stability of Close-Cell Al Foams Depending on The Usage of Different Foaming Agents, Mater. Tehnol., 49 (2015), 983-988

${ }^{9}$ M. Imam, V. Racherla, K. Biswas, H. Fujii, V. Chintapenta, Y. Sun, Y. Morisada, Microstructure-property relation and evolution in friction stir welding of naturally aged 6063 aluminium alloy, Int. J. Adv. Manuf. Technol., 91 (2017), 1753-1769, doi:10.1007/s00170016-9865-9

${ }^{10}$ Y. Liu, C. Geng, Q. Lin, Y. Xiao, J. Xu, W. Kang, Study on hot deformation behavior and intrinsic workability of 6063 aluminum alloys using 3D processing map, J. Alloys Compd., 713 (2017), 212-221, doi:10.1016/j.jallcom.2017.04.156

${ }^{11}$ X. Yao, Z. Zhang, Y. F. Zheng, C. Kong, M.Z. Quadir, J.M. Liang, Y.H. Chen, P. Munroe, D.L. Zhang, Effects of SiC Nanoparticle Content on the Microstructure and Tensile Mechanical Properties of Ultrafine Grained AA6063-SiCnp Nanocomposites Fabricated by Powder Metallurgy, J. Mater. Sci. Technol., 33 (2017), 1023-1030, doi:10.1016/j.jmst.2016.09.022

${ }^{12}$ Z. Liu, L. Li, J. Yi, S. Li, Z. Wang, G. Wang, Influence of heat treatment conditions on bending characteristics of 6063 aluminum alloy sheets, Trans. Nonferrous Met. Soc. China, 27 (2017), 1498-1506, doi:10.1016/S1003-6326(17)60170-5
${ }^{13}$ Y.-M. Zhang, X.-M. Chu, H. Wang, S.-Y. He, D.-P. He, Fabrication of $\mathrm{Al}-\mathrm{Mg}-\mathrm{Re}$ foams and their corrosion resistance properties, 51 (2009), 1436-1440, http://www.sciencedirect.com/science/article/ B6TWS-4VYXMR1-2/2/7efe698d7b89719ab21d24eaf6746c57

${ }^{14}$ L. de Lara, R. Jagdheesh, J. L. Ocana, Corrosion resistance of laser patterned ultrahydrophobic aluminium surface, Mater. Lett., 184 (2016), 100-103, doi:10.1016/j.matlet.2016.08.022

${ }^{15}$ I. Paulin, M. Godec, Surface oxidation of heating resistors made from Kanthal AF: Increasing the lifetime of glow plugs, Vacuum, 138 (2017), 146-151, doi:10.1016/j.vacuum.2016.12.007

${ }^{16}$ M. Torkar, A. Kocijan, R. Celin, J. Burja, B. Podgornik, Metallographic Investigation and Corrosion Resistance of Welds of Ferritic Stainless Steels, Mater. Tehnol., 50 (2016), 829-834, doi:10.17222/ mit.2016.059

${ }^{17}$ M. Conradi, A. Kocijan, Surface and Anticorrosion Properties of Hydrophobic and Hydrophilic $\mathrm{TiO}_{2}$ Coatings on A Stainless-Steel Substrate, Mater. Tehnol. 50 (2016), 967-970, doi:10.17222/mit. 2016.068

${ }^{18}$ N. Serban, D. Raducanu, M. Butu, V.D. Cojocaru, Crystallite Size and Lattice Strain Evolution in a Nanostructured 6063-T1 Aluminum Alloy Processed by Equal Channel Angular Pressing, Mater. Plast., 53 (2016), 179-183

${ }^{19}$ N. Serban, M. Butu, V.D. Cojocaru, Sustainable Lightweight 6063-T1 Aluminium Alloy Processed by Equal Channel Angular Pressing for Low Environmental Impact Applications, Mater. Plast., 53 (2016), 617-622

${ }^{20}$ Q. Liu, R.-H. Zhu, D.-Y. Liu, Y. Xu, J.-F. Li, Y.-L. Chen, X.-H. Zhang, Z.-Q. Zheng, Correlation between artificial aging and intergranular corrosion sensitivity of a new Al-Cu-Li alloy sheet, Mater. Corros., 68 (2017), 65-76, doi:10.1002/maco.201609090

${ }^{21}$ C. T. Kwok, K. H. Lo, W. K. Chan, F. T. Cheng, H. C. Man, Effect of laser surface melting on intergranular corrosion behaviour of aged austenitic and duplex stainless steels, Corros. Sci., 53 (2011), 1581-1591, doi:10.1016/j.corsci.2011.01.048

${ }^{22}$ A. S. Khanna, Introduction to High Temperature Oxidation and Corrosion, 2002

${ }^{23}$ A. H. M. Sanchez, B. J. C. Luthringer, F. Feyerabend, R. Willumeit, $\mathrm{Mg}$ and $\mathrm{Mg}$ alloys: How comparable are in vitro and in vivo corrosion rates? A review, Acta Biomater., 13 (2015), doi:10.1016/ j.actbio.2014.11.048

${ }^{24}$ C. Li, G. Sha, J. Xia, Y. Liu, S. P. Ringer, Si-induced precipitation modification and related age-hardening response of an Al-4Mg-1Cu-0.5Si alloy, Mater. Chem. Phys., 193 (2017), 421-426, doi:10.1016/j.matchemphys.2017.01.041

${ }^{25}$ Y. Li, Z. Shi, J. Lin, Y.L. Yang, Q. Rong, B. M. Huang, T. F. Chung, C. S. Tsao, J. R. Yang, D. S. Balint, A unified constitutive model for asymmetric tension and compression creep-ageing behaviour of naturally aged Al-Cu-Li alloy, Int. J. Plast., 89 (2017), 130-149, doi:10.1016/j.ijplas.2016.11.007

${ }^{26}$ T. O. Mbuya, B. O. Odera, S. P. Ng'ang'a, Influence of iron on castability and properties of aluminium silicon alloys: literature review, Int. J. Cast Met. Res., 16 (2003), 451-465, doi:10.1080/13640461. 2003.11819622 